\title{
Bloodroot (Sanguinaria canadensis L.) Extent and Sustainability in Western North Carolina
}

\author{
Jill Furgurson $^{1^{*}}$, Fred Cubbage ${ }^{2}$, Erin Sills ${ }^{2}$, Peter Bates ${ }^{3}$ \\ ${ }^{1}$ Department of Geography, University of North Carolina, Chapel Hill, USA \\ ${ }^{2}$ Department of Forestry and Environmental Resources, North Carolina State University, Raleigh, USA \\ ${ }^{3}$ Department of Geosciences and Natural Resources, Western Carolina University, Cullowhee, USA \\ Email: jjmfurgurson@unc.edu
}

Received June $13^{\text {th }}, 2012$; revised July $24^{\text {th }}, 2012$; accepted August $8^{\text {th }}, 2012$

\begin{abstract}
Bloodroot distribution and abundance were assessed in the Waynesville watershed in Western North Carolina. This high quality site provides a benchmark for bloodroot populations in the region. Summary data from an inventory of nine stands of bloodroot in the watershed are presented. Analysis of inventory data reveals that both petiole height and petiole diameter are negatively associated with overstory tree $\mathrm{DBH}$, suggesting that there is an optimal overstory structure for bloodroot. In the Waynesville watershed, seven out of nine stands have an average tree DBH between $27.38 \mathrm{~cm}$ and $36.17 \mathrm{~cm}$. Allometric equations relating belowground biomass to bloodroot petiole height and diameter have strong explanatory power, indicating that harvesters could selectively harvest large rhizomes by targeting plants with larger petioles. These results in combination with natural history, field observations and literature provide insights on the sustainability of bloodroot harvest in Southern Appalachia. Wild bloodroot is likely becoming scarce due to loss of favorable sites, such as rich cove forests, as well as harvest pressure.
\end{abstract}

Keywords: Bloodroot; Nontimber Forest Product; NTFP; Sustainability; Waynesville Watershed; Western North Carolina

\section{Introduction}

The forest plant bloodroot (Sanguinaria canadensis L.) is harvested from natural stands in the eastern United States for both artistic and medicinal uses. In order to ensure this resource is available for future generations, baseline information is required for establishing sustainable harvesting regimes. Density and size-class structure are essential data for determining sustainable harvest levels for nontimber forest products from natural forest ecosystems (Peters, 1994). Sustainable, as used in this study, has both biological and managerial dimensions. Harvests are sustainable if they allow the continuation of viable natural populations of the resource and should incorporate management practices that support indefinite yields. Additional goals include maintenance of biodiversity within natural stands, preservation of traditional knowledge, and generation of income for local communities.

\section{Bloodroot Uses and Sustainability}

Bloodroot is an herbaceous perennial plant that grows in rich well-drained forest soils (Predny \& Chamberlain, 2005; Greenfield \& Davis, 2004). Populations of the plant can be found from the Atlantic to the Rocky Mountains, and from southern Canada through the southern United States (Cech, 2002). In Western North Carolina, bloodroot is harvested for both medicinal and artistic uses and is currently used by the Eastern Band of Cherokee Indians as a dye plant for hand woven baskets, a tradition that goes back for hundreds of years. In recent years the plant has been considered as an alternative to syn-

\footnotetext{
"Corresponding author.
}

thetic antibiotics used in cattle feeds (Greenfield \& Davis, 2004), and bloodroot alkaloids have been studied as a component of cancer treatment medications (Nihal et al., 2000). Bloodroot is considered to be a nontimber forest product (NTFP) since nearly all harvesting is from natural stands, as opposed to cultivated sources. NTFPs are biological resources, such as medicinal plants, nuts, resins, dyes and ornamental plants, which can be harvested from the forest to provide income. Despite the widely touted conservation potential of NTFPs, ecological assessments of harvesting implications are rare (Ticktin, 2004). NTFPs offer local communities in Southern Appalachia a supplemental income from the forest and are important to local culture, but over-harvesting of wild populations could pose a threat to long term population viability.

Over-collection is an important factor in population decline of medicinal plants, and this is especially true of plants where the root, bark or whole plant is harvested (Hayden, 2005). Since the rhizome of bloodroot contains the desired medicinal compounds, the plant is especially susceptible to mortality following harvesting if careful collection practices are not followed. Members of the Eastern Band of Cherokee Indians recommend replanting a piece of the rhizome back into the ground while harvesting bloodroot in order to maintain viable populations. This practice is in accordance with recommended propagation methods, which suggest breaking the rhizome into small pieces, approximately one to two inches, for successful clonal propagation (Persons \& Davis, 2005).

As Greenfield and Davis (2004) report, increasing demand for bloodroot is putting pressure on naturally occurring populations. For centuries, the many uses of bloodroot have led to its being intensively harvested from North American forests. Al- 
though small quantities of dried bloodroot from wild stock can be found on the market, and some nurseries offer small volumes of cultivated stock, large volumes are not available from cultivated sources (Persons \& Davis, 2005). Conventional cultivation of forest medicinal plants can be cost prohibitive, which is one factor contributing to diminishing wild populations (Naud et al., 2009). The USDA Forest Service Southern Research Station (SRS) has recognized an increase in the harvesting of special forest products in the southeastern United States and associated threats to the long-term social, ecological and economic sustainability of these forest resources (Chamberlain, 2004).

The development of a management plan for a medicinal plant should incorporate knowledge from various sources. The Cherokee people utilized and influenced forest resources long before the development of forest science. In order to most effectively manage forest resources such as bloodroot, collaboration between local communities, government agencies and forest scientists is necessary. Understanding traditional knowledge regarding forest resources is an integral part of developing sustainable management plans. However, consumption patterns today differ from historical trends, and knowledge of the present state of the forest is also important for guiding management plans. With a greater demand for forest products, it is necessary to combine traditional knowledge of distribution and growth patterns with monitoring efforts and inventory analysis. Specifically, a forest inventory is necessary to ascertain the current distribution and abundance of the populations of the species under consideration (Peters, 1994).

\section{Case Study Overview}

We implemented a detailed bloodroot inventory in the Waynesville city watershed in Haywood County in western North Carolina. The site was chosen because of its mature forests that provide high-quality sites for bloodroot and because bloodroot harvest had not been allowed. The strategic man- agement plan for the watershed has the primary objective of maintaining a healthy and diverse forest to ensure a supply of high quality drinking water for the town of Waynesville. The preservation of unique plant species is a secondary objective, and although selective timber harvests occasionally occur, nearly all stands in the bloodroot growth areas contain trees of approximately 80 - 85 years.

A single resource inventory at one point in time allows quantification of the distribution and abundance of the resource and estimation of relationships pertinent to sustainable harvesting. In this case, inventory data on plant sizes and population densities from the Waynesville watershed in Western North Carolina are used to establish a baseline on biological supply of bloodroot in natural stands not subject to harvesting. This provides a reference point useful both for development of guidelines for sustainable levels of extraction and for assessment of the potential for this resource to be sustainably utilized. Further, we combine the data from this site with the literature on forest types in the Appalachians to estimate the extent of bloodroot in the region.

We also analyze the relationship between easily recognized aboveground characteristics (petiole height and petiole diameter) and belowground biomass of rhizomes. The ability to predict belowground biomass without actually harvesting the plant is critical for sustainable harvesting. Specifically, if harvesters can practice more selective harvesting, plant mortality rates may decline.

\section{Methods}

In the summer of 2006 , we canvassed sites with both protected and harvested stands of bloodroot. We measured the density of bloodroot and forest stand conditions in both types of sites and then focused on the 8030 acre tract of mature second growth forest that comprises the Waynesville watershed (Figure 1). The Waynesville watershed is a north-facing, rich forest cove site with trees approximately $80-85$ years old. It is a high

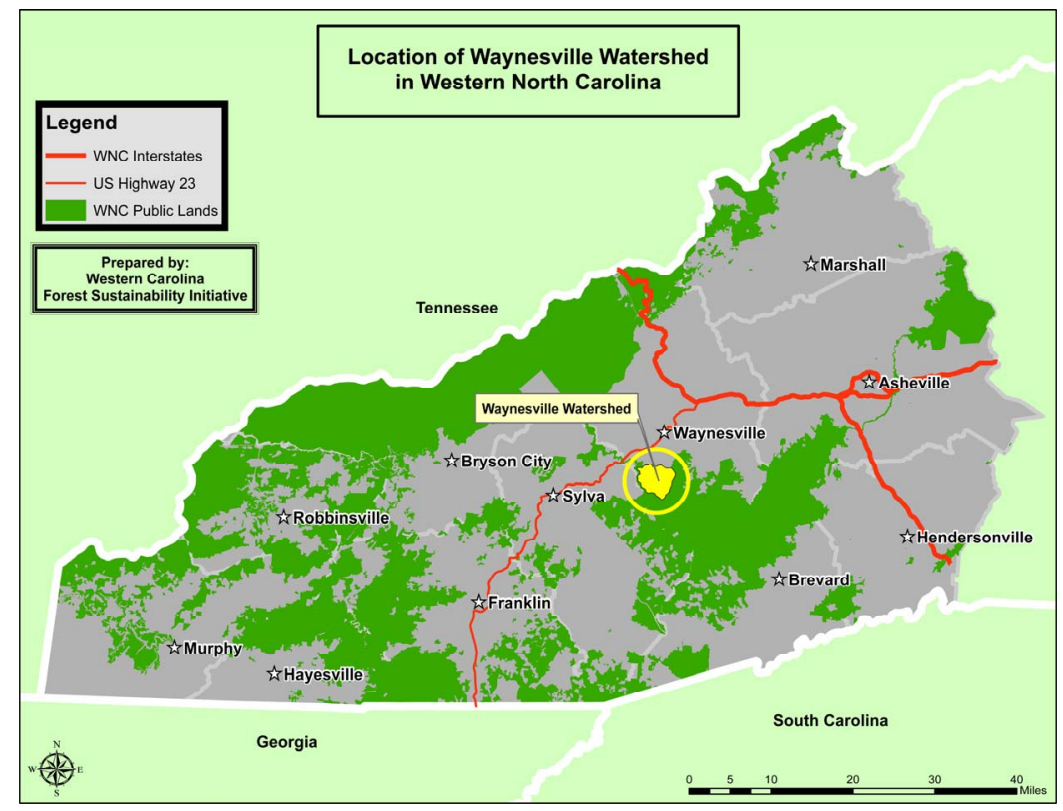

Figure 1.

Map of location of Waynesville watershed in Western North Carolina. 
quality mature hardwood forest with good soils and drainage, and provides high quality habitat for bloodroot growth. Situated within the Great Balsam Mountains/Pisgah Ridge Natural Heritage Megasite, the watershed is part of a natural heritage area recognized by the NC Natural Heritage Program (Conservation Trust for North Carolina, 2005). The watershed is managed under a conservation easement that limits timber harvests. Further, the bloodroot stands in the watershed are considered protected and not subject to harvesting.

\section{Bloodroot and Forest Sampling}

Bloodroot stands were defined as naturally isolated populations of individual plants geographically separated from other bloodroot growth areas. Random sampling, which can be time consuming and leave large sections of an area unsampled, is not always appropriate for inventories and monitoring of NTFPs (Kerns et al., 2002). Based on the literature (Predny \& Chamberlain, 2005; Persons \& Davis, 2005), we identified areas within the watershed likely to support bloodroot growth and then completely surveyed these areas. The identified areas were based on forest type and all rich cove, mesic and northern hardwood stands were sampled. All stands of bloodroot identified were inventoried to provide a census of bloodroot populations within the watershed.

The width and length of the identified stands were measured and then a central transect was created that ran the entire length of the stand. Petiole height (from the soil surface) and petiole diameter at ground level were measured for all plants growing within one half meter of either side of the transect. The total number of plants measured was 2789. Data were also collected on species and DBH of overstory trees, as well as stand elevation.

The analyses of above and belowground biomass relationships were based on 174 plants harvested from the Waynesville watershed between July 25 and August 4, 2006. Occasionally, one bloodroot rhizome can support several stems. Since the intent was to examine the relationship between above ground leaf characteristics and rhizome mass, only rhizomes supporting one petiole were measured.

The length and wet weight of rhizomes were measured. Rhizomes were weighed wet so that they could be replanted directly following measurement. However, the rhizomes are usually marketed in a dried form.

\section{Statistical Analyses}

A one-way analysis of variance (ANOVA) test was performed to detect differences among stands in density of bloodroot (using JMP from SAS). The relationships between the aboveground plant characteristics of petiole height and diameter and tree dbh were analyzed with ordinary least squares (OLS) regression analysis, using a robust estimator for clustering by stand (using LIMDEP). We also estimated OLS regressions of rhizome biomass as a function of petiole height and petiole diameter to identify relationships between the aboveground plant characteristics and below ground biomass. Following the methods of Ott and Longnecker (2001), all analyses were conducted with and without an outlier stand that is exceptionally small and that has an exceptionally high density of bloodroot. We included intercepts in all regressions, as recommended by Bond-Lamberty et al. (2002).

\section{Results}

\section{Bloodroot Extent}

Bloodroot was found growing on approximately 34.8 acres $\left(141,445 \mathrm{~m}^{2}\right)$ of the 433 acres $\left(1,752,000 \mathrm{~m}^{2}\right)$ of suitable habitat cruised on the Waynesville watershed, or about 4.2 percent of the watershed. The bloodroot was distributed across the watershed in nine stands, of which eight are located on northern hardwood slopes or poplar coves. The ninth stand is located in a mesic oak-hickory stand. The statistics for the nine bloodroot stands are summarized in Table 1 . The bloodroot stands vary in dimensions, from $2.2 \times 2.4$ to $395 \times 140$ meters. Eight of the nine stands have a mean area of $17,679 \mathrm{~m}^{2}$, while an outlier stand has an area of just $5.28 \mathrm{~m}^{2}$. Average bloodroot densities for the nine stands vary from 1.68 to 35.42 plants per square meter. These values are based on the density measurements obtained from sampling along the central transect and are used for the ANOVA analyses. Eight out of nine of the stands have average densities of 6.77 plants per square meter or lower. The small stand with a density of 35.42 plants per square meter is unusual when compared to all other stands sampled and canvassed for this study, and thus is treated as an outlier.

The petiole height of bloodroot plants in the Waynesville watershed varies from $7.62 \mathrm{~cm}$ to $33.02 \mathrm{~cm}$ and petiole diameter ranges from $0.08 \mathrm{~cm}$ to $0.75 \mathrm{~cm}$. Average petiole heights at the stand level vary from $13.94 \mathrm{~cm}$ to $26.39 \mathrm{~cm}$ and average petiole diameters at the stand level vary from $0.23 \mathrm{~cm}$ to 0.40 $\mathrm{cm}$.

The average tree diameter at breast height $(\mathrm{DBH})$ of the overstory trees measured in each stand varies from $15.27 \mathrm{~cm}$ to $31.83 \mathrm{~cm}$. However, 7 out of 9 stands have an average tree $\mathrm{dbh}$ between $27.38 \mathrm{~cm}$ and $36.17 \mathrm{~cm}$. Tree species richness, defined as the number of overstory tree species identified within the stand, ranges from four to eight species. The most common species are tulip poplar, red oak, hickory and white oak.

The results of the one way ANOVA revealed that there were no significant statistical differences $(\alpha=0.05)$ in mean densities among the nine bloodroot stands in the Waynesville watershed $(\mathrm{F}=2.583 ; \mathrm{df}=1.7 ; p=0.152)$, even including the outlier stand. Excluding the outlier stand, the F statistic drops to 0.092, with a $p$ value of 0.772 .

Average petiole height is significantly negatively correlated with average tree $\mathrm{dbh}$ ( coefficient $_{\mathrm{dbh}}=-1.2, p$-value $=0.02, \mathrm{R}^{2}$ $=0.67, \mathrm{df}=2788)$. Average petiole diameter is also negatively correlated with average tree dbh ( coefficient $_{\mathrm{dbhl}}=-0.02, p$-value $=0.05, \mathrm{R}^{2}=0.34, \mathrm{df}=2788$ ). In stands with larger overstory trees, bloodroot plants tend to be smaller, whether measured by petiole height or diameter.

\section{Relationship between Aboveground Form and Belowground Volume}

Site-specific allometric equations were developed relating the aboveground plant characteristics of petiole height and petiole diameter to the belowground biomass of rhizomes. Simple linear regressions of rhizome weight on each of these characteristics were statistically significant for petiole height, $\mathrm{R}^{2}=0.65, p_{\text {model }}<0.0001$ (Figure 2); and for petiole diameter, $\mathrm{R}^{2}=0.73 ; p_{\text {model }}<0.0001$ (Figure 3 ). Thus, diameter has the greatest explanatory power.

A single multiple regression was estimated after controlling for petiole characteristics and confirms that the model continues 
Table 1.

Bloodroot stand inventory data.

\begin{tabular}{cccccc}
\hline Stand number & Average density $($ plants $/ \mathrm{m})$ & Average petiole height $(\mathrm{cm})$ & Average petiole diameter $(\mathrm{cm})$ & Average tree dbh $(\mathrm{cm})$ & Count of tree species \\
\hline 1 & 35.42 & 26.39 & 0.40 & 15.27 & 5 \\
2 & 5.99 & 16.18 & 0.26 & 36.17 & 4 \\
3 & 2.09 & 19.61 & 0.34 & 27.99 & 5 \\
4 & 2.10 & 18.14 & 0.29 & 28.55 & 7 \\
5 & 1.68 & 18.13 & 0.29 & 27.38 & 5 \\
6 & 6.77 & 16.33 & 0.25 & 27.94 & 8 \\
7 & 1.82 & 16.93 & 0.26 & 29.64 & 5 \\
9 & 3.31 & 15.58 & 0.23 & 30.12 & 6 \\
\hline
\end{tabular}

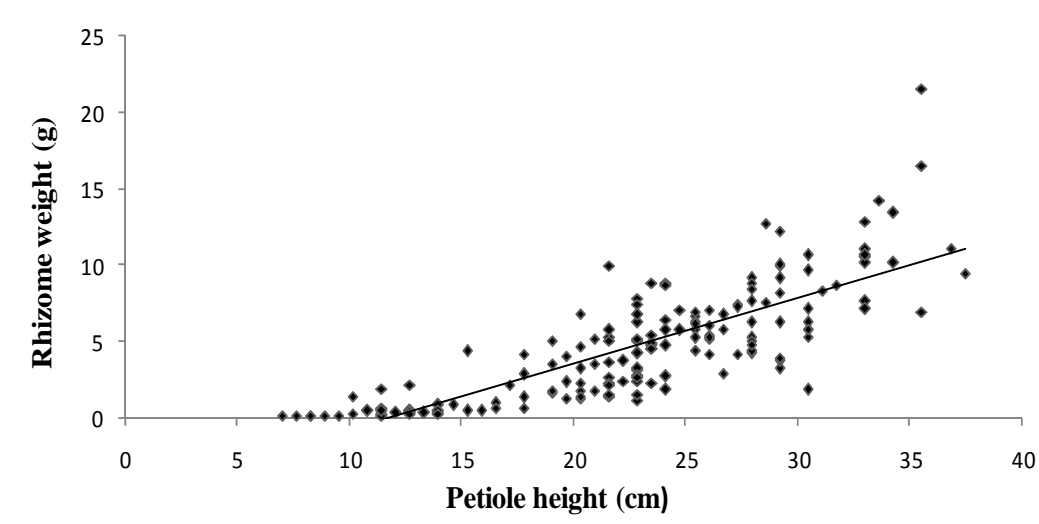

Figure 2.

Scatter plot and fitted simple linear regression of bloodroot rhizome weight on stem height, $\mathrm{N}=174$, Rhizome weight $(\mathrm{g})=-5.1387+0.4319$ (petiole height); $\mathrm{R}^{2}=0.65 ; p<0.0001$.

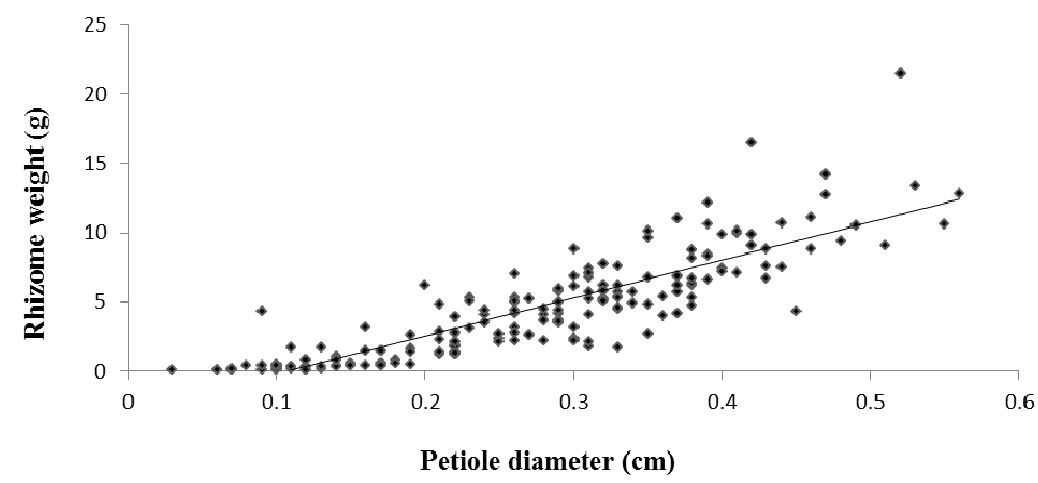

Figure 3.

Scatter plot and fitted simple linear regression of bloodroot rhizome weight on stem diameter, $\mathrm{N}=174$, Rhizome weight $(\mathrm{g})=-2.9825+27.5459$ (petiole diameter); $\mathrm{R}^{2}=0.73 ; p<0.0001$.

to provide a good fit for the data $\left(\mathrm{R}^{2}=0.77, p_{\text {model }}<0.0001\right)$, and the coefficients on both petiole height and diameter remained significant at the $1 \%$ level. The allometric equation for predicting belowground rhizome biomass with only these statistically significant predictor variables of petiole height and petiole diameter is:
Rhizome weight $(\mathrm{g})=-4.6284+0.1802$ (petiole height) + 18.7254 (petiole diameter).

\section{Discussion}

While nontimber forest products have received increasing 
attention (Shackleton et al., 2011, Kerns et al., 2002, Ticktin, 2004), our research found relatively little literature relating to their sustainable harvest (Wong, 2000). We did not find any research recommending guidelines for harvest of bloodroot. In order to address this gap in the scientific literature, this study provides plant size and stand density information for nine stands of protected bloodroot in the Waynesville watershed of North Carolina. We also analyzed the relationship between easily observable aboveground plant characteristics and belowground biomass, which could contribute to guidelines for sustainable harvest of the resource. In this section, we complement the analyses with a brief discussion of the distribution and long term sustainability of bloodroot in western North Carolina to provide context for comparisons between the protected stands that we inventoried and nearby harvested stands.

\section{Waynesville Case Study}

In the Waynesville watershed, we found that most bloodroot (eight of the nine stands identified) occurs on northern hardwood slopes or poplar coves. Within this habitat type, bloodroot stands have a clumped distribution. Eight stands had similar characteristics. While the mean density of the ninth stand was not statistically different at the $15 \%$ level, it was much higher than the other stands in absolute terms. This may be due to unusual stand characteristics also reflected in its small size. Bloodroot is known to respond to increased sunlight through increased clonal growth (Marino et al., 1997), and the stand was located in a patch of sunlight with little overstory cover, possibly the result of a treefall gap.

Mean petiole diameter of the bloodroot stands is significantly negatively correlated with average overstory tree dbh within the range of conditions where bloodroot was found. It is important to note that excluding the outlier population, all of the stands are located within areas where average tree $\mathrm{dbh}$ is between 27.38 and $36.17 \mathrm{~cm}$. Bloodroot is not found growing naturally in large open fields or in very young stands with a low mean tree dbh and lots of competitive herbaceous cover. Preliminary literature review and canvassing of possible research sites indicated that bloodroot is not found in young stands or dry sites. Rather, typical sites for bloodroot are medium-sized hardwood stands on northern aspects. As the mean dbh of mature stands increases, bloodroot growth may decline. One explanation for this is that an older mature overstory of large hardwood trees allows more light to reach the forest floor and increases the competition from other understory plants. It is also possible that increased tree growth results in limited nutrients, which may in turn lead to a decline in bloodroot growth rates.

\section{Allometric Volume Equations}

The relationship between easily recognized aboveground characteristics (petiole height and petiole diameter) and belowground biomass of rhizomes was analyzed to assess the feasibility of restricting harvest to the largest rhizomes. Regression analyses based on the 174 harvested rhizomes and their corresponding aboveground plant parts reveal that rhizome biomass can be predicted fairly accurately with two variables: petiole height $(\mathrm{cm})$ and petiole diameter $(\mathrm{cm})\left(\mathrm{R}^{2}=0.77 ; p<0.0001\right)$. The regression equations demonstrate that harvesters can estimate belowground biomass based on the observable above ground plant characteristics of petiole height and petiole diameter.

\section{Regional Bloodroot Sustainability}

In a preliminary reconnaissance made when selecting the Waynesville study site, four additional forests in Western North Carolina were visited, including a national forest research site and private and community forests. This confirmed that rich cove sites provide excellent habitat for bloodroot.

Field observations and a few sample plots were taken in one of the sites that had been open to bloodroot harvests and subject to periodic timber harvests. Bloodroot on these lands was scarce, even on rich cove sites comparable to those sampled in the Waynesville watershed. The plants had comparable mean petiole heights to those on the Waynesville watershed, but stand densities were notably reduced.

Thus, our inventory may provide an upper bound on bloodroot distribution and abundance, since the Waynesville site is managed under a conservation easement and not subject to bloodroot harvest. Based on our canvass of potential sites, the mean density of harvested stands was less than one plant per square meter compared to 7.2 plants per square meter in the Waynesville watershed. If the Waynesville high density stand outlier is removed, the mean stand density drops to 3.7 plants per square meter, still significantly larger than the harvested stands. Due to the similarity in forest types and bloodroot plant sizes, it is likely that this discrepancy in stand density is due to harvesting pressure. This in turn suggests that some regulation of harvest (whether by law or by community norms) and/or active management such as enrichment plantings will be required to prevent further decline of bloodroot populations.

According to work on the ecological zones of the Southern Appalachian Mountains by Simon et al. (2005), 12 percent $(695,000$ acres) of the Southern Appalachian Mountains are in Northern Hardwood or Rich Cove ecological zones. If the Waynesville watershed can be considered representative of Southern Appalachia, then we can extrapolate from the occurrence of bloodroot in $4.2 \%$ of the suitable habitat in Waynesville to estimate that there are 56,000 acres of bloodroot in the Southern Appalachian Mountains. This represents less than one percent of the total forest area. If the 1,772,000 acres of Mesic Oak-Hickory (Simon et al., 2005) are added to the total area of suitable habitat, the total potential bloodroot area would be about 197,000 or 3.4 percent of total forest area, although this is likely an over-estimate, because we found only one bloodroot stand in this forest type.

Furthermore, anecdotal evidence indicates that bloodroot may be more common in the Waynesville watershed than in the region as a whole, suggesting that the total area occupied by bloodroot in Southern Appalachia is even less than projected above. Sampling more stands under a variety of ownership and management types would shed further light on whether the Waynesville stands are representative and whether diminished stand density is typical of sites that are open to harvest. Last we offer a few observations about the natural history of bloodroot and forest management practices. Bloodroot clearly favors deep rich soils on north and east facing slopes and rich cove sites, as well as soils that are not too acidic, which leads to domination by rhododendron. Most of the Waynesville watershed has this combination of aspect and soils. Furthermore, though not well documented, our results suggest that bloodroot thrives under a certain age, species, and density of forest overstory. Most of the forest in the Waynesville watershed is about 80 - 85 years old with a general oak-hickory-poplar forest composition, and a 
moderate stand density. The few additional areas where we observed bloodroot were mature stands with trees 60 to 100 years old, which prevented lush vegetation on the forest floor, thus allowing the less competitive bloodroot to prosper. Recent clearcuts and young stands with trees 30 - 50 years old had no observable bloodroot at all. The dense vegetation of pioneer species and young saplings resulting in nearly complete forest floor cover may prevent bloodroot survival. This implies that older stands of oak-hickory-poplar on good sites are required to nurture bloodroot, which in turn suggests that landowners face a trade-off between timber and non-timber production: tracts of valuable old growth timber should be left unharvested where conservation of bloodroot is a high priority.

\section{Acknowledgements}

We would like to thank the City of Waynesville for allowing us to conduct our research on their watershed. We would also like to thank the USDA Forest Service Health Monitoring Program. We are grateful to the Revitalization of Traditional Cherokee Artisan Resources (RTCAR) and the Community Forestry \& Environmental Research Partnerships for funding. We thank Seth Holling for assistance in the field and Drs. Jeanine Davis and David Danehower for valuable discussion and insight.

\section{REFERENCES}

Bond-Lamberty, B., Wang, C., \& Gower, S. T. (2002). Aboveground and belowground biomass and sapwood area allometric equations for six boreal tree species of northern Manitoba. Canadian Journal of Forest Research, 32, 1441-1450. doi:10.1139/x02-063

Cech, R. (2002). Growing at-risk medicinal herbs: Cultivation, conservation and ecology. Williams, OR: Horizon Herbs.

Chamberlain, J. (2004). Special forest products: A southern strategy for research and technology transfer. Washington DC: USDA Forest Service Publication.

Conservation Trust for North Carolin (2005). Waynesville's clean drinking water protected. Raleigh, NC: Conservation Trust for North
Carolina.

Greenfield, J., \& Davis, J. M. (2004). Medicinal herb production guide: Bloodroot (Sanguinaria canadensis L.). Raleigh, NC: North Carolina Consortorium on Natural Medicines and Public Health.

Hayden, L. (2005). The role of herbalism in the loss of native plants of the northeast. Rhode Island Naturalist, 12, 1-3.

Kerns, B. K., Liegel, L., Pilz, D., \& Alexander, S. J. (2002). Biological inventory and monitoring. In E. T. Jones, R. J. McClain, \& J. Weigand (Eds.), Non-timber forest products in the United States. Lawrence, KS: University Press of Kansas.

Marino, P. C., Eisenberg, R. M., \& Cornell, H. V. (1997). Influence of sunlight and soil nutrients on clonal growth and sexual reproduction of the understory perennial herb Sanguinaria canadensis L. Journal of the Torrey Botanical Society, 124, 219-227. doi:10.2307/2996609

Naud, J., Olivier, A., Belanger, A., \& Lapointe, L. (2009). Medicinal understory herbaceous species cultivated under different light and soil conditions in maple forests in Southern Quebec. Agroforestry Systems, 79, 303-326.

Nihal, A., Gupta, S., \& Husain, M. M. (2000). Differential antiproliferative response of sanguinarine for cancer cells versus normal cells. Clinical Cancer Research, 6, 1524-1528.

Ott, R. L. \& Longnecker, M. (2001). An introduction to statistical methods and data analysis (5th ed.). Duxbury: Thomson Learning.

Persons, W. S., \& Davis, J. M. (2005). Growing and marketing ginseng, goldenseal, and other woodland medicinals. Fairview, NC: Bright Mountain Books.

Peters, C. M. (1994). Sustainable harvest of non-timber plant resources in tropical moist forest: An ecological primer. Biodiversity Support Group.

Predny, M. L., \& Chamberlain, J. L. (2005). Bloodroot (Sanguinaria canadensis): An annotated bibliography. US Department of Agriculture, Forest Service, Southern Research Station.

Shackleton, S., Shackleton, C., \& Shanley, P. (Eds.) (2011). Non-timber forest products in the global context. Tropical Forestry, 7, 3-21. doi:10.1007/978-3-642-17983-9 1

Simon, S. A., Collins, T. K., Kauffman, G. L., McNab, W. H., \& Ulrey, C. J. (2005). Ecological zones in the Southern Appalachians: First Approximation. USDA Forest Service Southern Research Station.

Ticktin, T. (2004). The ecological implications of harvesting non-timber forest products. Journal of Applied Ecology, 41, 11-21. doi:10.1111/j.1365-2664.2004.00859.x 